\title{
1 Development and Implementation of Dried Blood Spot-based COVID-19 Serological Assays
}

\section{2 for Epidemiologic Studies}

4 Marcus P Wong ${ }^{1}$, Michelle A Meas ${ }^{1}$, Cameron Adams², Samantha Hernandez ${ }^{1}$, Valerie Green ${ }^{3}$,

5 Magelda Montoya ${ }^{1}$, Brett M Hirsch ${ }^{4}$, Mary Horton ${ }^{2}$, Hong L Quach ${ }^{2}$, Diana L Quach ${ }^{2}$, Xiaorong

$6 \mathrm{Shao}^{2}$, Indro Fedrigo ${ }^{2}$, Alexandria Zermeno ${ }^{1}$, Julia Huffaker ${ }^{1}$, Raymond Montes $^{1}$, Alicia Madden ${ }^{1}$,

7 Sherri Cyrus $^{3}$, David McDowell ${ }^{3}$, Phillip Williamson ${ }^{3}$, Paul Contestable ${ }^{4}$, Mars Stone ${ }^{5,6}$, Josefina

8 Coloma $^{1}$, Michael P Busch ${ }^{5,6^{*}}$, Lisa F Barcellos $^{2 *}$ Eva Harris ${ }^{1 * \#}$

$10{ }^{1}$ Division of Infectious Diseases and Vaccinology, School of Public Health, University of

11 California, Berkeley, Berkeley, CA, USA

12 Division of Epidemiology, School of Public Health, University of California, Berkeley, Berkeley,

13 CA, USA

$14 \quad{ }^{3}$ Creative Testing Solutions, Tempe, AZ, USA

$15{ }^{4}$ Ortho Clinical Diagnostics, Rochester, NY, USA

$16{ }^{5}$ Vitalant Research Institute, San Francisco, CA, USA

$17{ }^{6}$ Department of Laboratory Medicine, University of California, San Francisco, CA, USA

$18 *$ Co-senior authors contributed equally to this work

20 Running Head: Dried Blood Spots for SARS-CoV-2 Serosurveillance

22 \#Address correspondence to Eva Harris, eharris@,berekeley.edu 
medRxiv preprint doi: https://doi.org/10.1101/2021.11.25.21266786; this version posted November 28, 2021. The copyright holder for this preprint (which was not certified by peer review) is the author/funder, who has granted medRxiv a license to display the preprint in perpetuity.

It is made available under a CC-BY-NC-ND 4.0 International license .

\section{$24 \underline{\text { Abstract }}$}

25 Serological surveillance studies of infectious diseases provide population-level estimates of

26 infection and antibody prevalence, generating crucial insight into population-level immunity, risk

27 factors leading to infection, and effectiveness of public health measures. These studies traditionally

28 rely on detection of pathogen-specific antibodies in samples derived from venipuncture, an

29 expensive and logistically challenging aspect of serological surveillance. During the COVID-19

30 pandemic, guidelines implemented to prevent the spread of SARS-CoV-2 infection made

31 collection of venous blood logistically difficult at a time when SARS-CoV-2 serosurveillance was

32 urgently needed. Dried blood spots (DBS) have generated interest as an alternative to venous blood

33 for SARS-CoV-2 serological applications due to their stability, low cost, and ease of collection;

34 DBS samples can be self-generated via fingerprick by community members and mailed at ambient

35 temperatures. Here, we detail the development of four DBS-based SARS-CoV-2 serological

36 methods and demonstrate their implementation in a large serological survey of community

37 members from 12 cities in the East Bay region of the San Francisco metropolitan area using at-

38 home DBS collection. We find that DBS perform similarly to plasma/serum in enzyme-linked

39 immunosorbent assays and commercial SARS-CoV-2 serological assays. In addition, we show

40 that DBS samples can reliably detect antibody responses months post-infection and track antibody

41 kinetics after vaccination. Implementation of DBS enabled collection of valuable serological data

42 from our study population to investigate changes in seroprevalence over an eight-month period.

43 Our work makes a strong argument for the implementation of DBS in serological studies, not just

44 for SARS-CoV-2, but any situation where phlebotomy is inaccessible. 
medRxiv preprint doi: https://doi.org/10.1101/2021.11.25.21266786; this version posted November 28, 2021. The copyright holder for this preprint (which was not certified by peer review) is the author/funder, who has granted medRxiv a license to display the preprint in perpetuity.

It is made available under a CC-BY-NC-ND 4.0 International license .

\section{$47 \quad$ Introduction}

48 Serological surveillance of infectious diseases provides estimates of the incidence and prevalence

49 of infections, generating actionable public health knowledge - such as which populations are

50 disproportionately affected by an infectious disease outbreak or the effectiveness of public health

51 measures in curbing infections. SARS-CoV-2, the causative agent of the COVID-19 pandemic, is

52 responsible for at least 250 million infections and 5 million deaths since its emergence in late 2019

53 to date (1). Given that approximately $35 \%$ of all SARS-CoV-2 infections are asymptomatic $(2,3)$,

54 with proportions varying substantially by age, serological surveillance studies are a critical tool to

55 enable estimation of the incidence of recent infection and prevalence of past infections at the

56 population level. Most serological studies rely on venous blood from study participants to derive

57 plasma or serum and therefore require an invasive phlebotomy procedure and an intact cold chain

58 for collection, shipment, and storage to ensure sample stability prior to testing. However, during

59 the COVID-19 pandemic, implementation of public health guidelines to curb the spread of SARS-

$60 \mathrm{CoV}-2$, such as lockdowns and social distancing, made the collection of blood to obtain serum or

61 plasma for serosurveillance studies logistically challenging, especially for sizeable community-

62 based studies focused on a large geographic region.

63 Dried blood spots (DBS) are an alternative blood collection method for serological testing and

64 have been used extensively in screening for other viruses, including Hepatitis B, HIV, and Ebola

65 in both clinical and non-clinical settings (4-6). DBS have advantages over traditional venous blood

66 sampling (7): DBS are stable at room temperature for extended periods of time and can be easily

67 shipped by mail and stored (8), DBS require considerably less blood than traditional phlebotomy,

68 and DBS can be collected by study participants themselves via fingerprick. These qualities make 
medRxiv preprint doi: https://doi.org/10.1101/2021.11.25.21266786; this version posted November 28, 2021. The copyright holder for this preprint (which was not certified by peer review) is the author/funder, who has granted medRxiv a license to display the preprint in perpetuity.

It is made available under a CC-BY-NC-ND 4.0 International license .

69 DBS an attractive alternative to venous blood collection, especially when traditional phlebotomy

70 is inaccessible, such as in resource-poor settings or because of pandemic-related public health

71 restrictions.

72 There has been interest in developing DBS-based serological methods for SARS-CoV-2

73 serosurveillance. Several studies have investigated the feasibility and performance of DBS-based

74 serological assays, including enzyme-linked immunosorbent assays for anti-spike (S) and receptor

75 binding domain (RBD) antibodies (9-13), as well as multiplexed assay formats for simultaneous

76 detection of spike, RBD, and nucleocapsid (N) antibodies (14). Commercial assays on automated

77 platforms like the Roche Elecsys, which can detect anti-N or anti-S antibodies, have also been

78 evaluated for use with DBS samples. These assays have the advantage of high-throughput

79 processing and lower personnel requirements $(15,16)$. Based on testing paired plasma/serum and

80 DBS samples, these studies demonstrated robust agreement between the sample types. In addition,

81 several studies have shown that serological assays performed on DBS samples prepared by study

82 participants in the home and mailed to labs for processing can reliably detect SARS-Cov-2

83 antibodies, providing evidence that DBS are a promising alternative to plasma or serum for SARS-

84 CoV-2 serosurveillance $(13-15,17)$. However, implementation of DBS-adapted serological

85 methods for large community-based serological surveillance has not been widely demonstrated for

86 tracking immune responses due to natural infections and COVID-19 vaccines.

87 In this study, we present the validation of four DBS-based serological assays against SARS-CoV-

$882 \mathrm{~S}$ and $\mathrm{N}$ antibodies and detail their implementation in a large, serological survey with at-home

89 sample collection, as well as in ancillary longitudinal vaccine studies. We assessed the

90 performance of DBS-based lab-developed anti-S and anti-N IgG ELISAs and two commercial 
medRxiv preprint doi: https://doi.org/10.1101/2021.11.25.21266786; this version posted November 28, 2021. The copyright holder for this preprint (which was not certified by peer review) is the author/funder, who has granted medRxiv a license to display the preprint in perpetuity.

It is made available under a CC-BY-NC-ND 4.0 International license .

91 assays (the Ortho anti-S and Roche anti-N Total Ig assays) and evaluated their ability to detect

92 long-term antibody responses and vaccine-induced antibody kinetics. Using these assays in a serial

93 testing algorithm, we analyzed a total of 14,782 DBS samples from a longitudinal cohort of

94 individuals living in 12 cities in the East Bay region of the San Francisco metropolitan area at 3

95 timepoints between July 2020 and April 2021 for antibodies against SARS-CoV-2 S and N. Results

96 from this study demonstrate that DBS are a practical sampling method for serology-based

97 epidemiology studies, enabling in-home self-sampling for serosurveillance in situations where

98 traditional phlebotomy is inaccessible, impractical, or too costly.

99

$100 \quad$ Methods

101 Materials:

102 We obtained DBS cards (Tropbio Filter Paper Blood Collection Disks) from Cellabs. Reagents for

103 the DBS Elution Buffer $\left(63 \mathrm{mM} \mathrm{K}_{2} \mathrm{HP}_{4}, 28 \mathrm{mM} \mathrm{KH}_{2} \mathrm{PO}_{4}, 139 \mathrm{mM} \mathrm{NaCl}^{2} \mathrm{~g} / \mathrm{L}\right.$ Sodium Azide, $5 \mathrm{~g} / \mathrm{L}$

104 Caesin, 50g/L Probumin BSA in $\mathrm{H}_{2} 0$ ) were obtained from Sigma-Aldrich. SARS-CoV-2 soluble

105 trimeric S and N proteins used in ELISAs developed at UC Berkeley were provided by Dr. John

106 Pak (Chan-Zuckerberg Biohub) and Dr. Aubree Gordon (University of Michigan), respectively.

Human Subjects Ethics Statement

108 Samples for DBS validation studies were collected from participants consented under IRB \#11-

10906262 approved by the University of California, San Francisco Committee on Protection of Human

110 Subjects. Use of samples from convalescent plasma donors but did not involve human subjects

111 based on anonymization of data and routine consent for blood donation testing that includes use

112 of residual samples for research purposes. Samples for validation of the S and N IgG ELISAs were 
medRxiv preprint doi: https://doi.org/10.1101/2021.11.25.21266786; this version posted November 28, 2021. The copyright holder for this preprint (which was not certified by peer review) is the author/funder, who has granted medRxiv a license to display the preprint in perpetuity.

It is made available under a CC-BY-NC-ND 4.0 International license.

113 obtained from Dr. Benjamin Pinsky (Stanford University) and Dr. Bryan Greenhouse (UC San

114 Francisco) and were pre-collected and de-identified.

115

116 All participants in the East Bay COVID study provided informed consent for the initial screening

117 phase of the study. All those participating in the sampling phase of the study provided their

118 informed consent for each sample/data collection round. The study was approved by the University

119 of California, Berkeley Committee on Protection of Human Subjects (Protocol \#2020-03-13121).

$120 \quad$ Validation Studies

121 Plasma and DBS samples were collected from COVID-19 convalescent patients and SARS-CoV-

122 2-infected individuals. Reconstituted DBS were generated by mixing plasma with anticoagulated,

123 plasma-depleted whole blood and spotted on DBS cards. Four sets of samples were generated for

124 validation studies. The first sample set consisted of 39 paired plasma and reconstituted DBS

125 samples from previously SARS-CoV-2-infected individuals and 100 paired samples from

126 individuals without previous SARS-CoV-2 infection. The second sample set consisted of paired

127 plasma and reconstituted DBS from 10 COVID-19 convalescent plasma donors sampled

128 longitudinally between 0 and 246 days from their first donation. The third set of samples consisted

129 of paired plasma and fingerstick DBS samples generated from 12 vaccinated individuals sampled

130 before their first dose, after their first dose, and after their second dose. Four other vaccinated

131 individuals were sampled by fingerstick DBS over a period of 210 days, after their first, second,

132 and third doses. The plasma-based $\mathrm{S}$ and $\mathrm{N}$ IgG ELISAs IgG ELISA were validated using

133 convalescent plasma samples collected $>8$ days post-symptom onset from 60 hospitalized, PCR-

134 confirmed severe COVID-19 cases, 57 mild or subclinical cases, and samples collected before

1352020 from 131 unexposed persons as described previously (18). 
medRxiv preprint doi: https://doi.org/10.1101/2021.11.25.21266786; this version posted November 28, 2021. The copyright holder for this preprint (which was not certified by peer review) is the author/funder, who has granted medRxiv a license to display the preprint in perpetuity.

It is made available under a CC-BY-NC-ND 4.0 International license .

136

137

138

139

140

141

142

143

144 also utilized.

145 Of the 16,115 residents who consented and completed the screening procedures between May-July

$1462020,1,777$ individuals did not meet the inclusion criteria and were excluded (Figure 1). Eligible

147 participants were required to be the household member with the next birthday, live within the study

148 region, be willing to provide biospecimens (including DBS) and questionnaire responses, read and

149 speak English or Spanish, and have internet access and a valid email address.

150 The target sample size for the sampling phase was 5,500 participants. To obtain a sample that

151 resembled the racial and ethnic proportions reported in the 2018 American Community Survey

152 (ACS) for the study region, we ranked screening participants for study inclusion. Black and/or

153 Hispanic individuals were ranked the highest $(n=1,556)$ followed by other non-White individuals

$154(n=1,939)$. White individuals were randomly ranked to complete the remaining participant slots.

155 Individuals ranked between 1 and 5,500 were offered study enrollment, and non-respondents were

156 replaced with the next highest ranked individuals who had not yet been offered study entry. 
medRxiv preprint doi: https://doi.org/10.1101/2021.11.25.21266786; this version posted November 28, 2021. The copyright holder for this preprint (which was not certified by peer review) is the author/funder, who has granted medRxiv a license to display the preprint in perpetuity.

It is made available under a CC-BY-NC-ND 4.0 International license .

157 Biospecimens and questionnaire data were collected during three sampling rounds. Approximate

158 dates for each round were July-September 2020, October-December 2020, and February-April

159 2021. For each round of data and biospecimen collection, individuals who had participated in the

160 previous round were contacted to confirm their willingness to participate in the next round. If

161 participation was declined, individuals from the pool of screening participants who had not yet

162 participated in a sampling round were invited as needed. This resulted in 5,501 participants in

163 Round 1, 5,603 participants in Round 2, and 4,806 participants in Round 3 (Figure 1). This

164 corresponds to participation rates of $76.8 \%, 89.8 \%$, and $87.3 \%$ across the study rounds,

165 respectively. A biospecimen collection kit was developed and assembled by investigators and sent

166 to each participant via Federal Express (FedEx). Both written instructions and an instructional

167 video for at-home sample collection, including fingerstick blood sampling and preparation of DBS,

168 were provided to all study participants. Both English and Spanish versions were made available.

\section{Quality Control of DBS}

170 DBS received from participants were assessed for quality. We evaluated each DBS on a scale from

1710 to 3, with 0 representing a blank DBS, 1 representing an incompletely filled DBS on one side, 2

172 representing a DBS card saturated fully on only one side, and 3 representing a DBS fully saturated

173 on both sides. Participants who provided at least two DBS samples with a cumulative score of 2

174 or higher were processed in our serological assays; samples that did not meet this criterion were

175 labelled as "Quality Not Sufficient" (QNS).

177 Two DBS were removed from the Tropbio disk and placed in a 2-mL screwcap tube. Five hundred

$178 \mathrm{uL}$ of elution buffer was added into the tube and vortexed for 20 seconds. If DBS numbers were 
medRxiv preprint doi: https://doi.org/10.1101/2021.11.25.21266786; this version posted November 28, 2021. The copyright holder for this preprint (which was not certified by peer review) is the author/funder, who has granted medRxiv a license to display the preprint in perpetuity.

It is made available under a CC-BY-NC-ND 4.0 International license .

179 limited, one spot was eluted in $250 \mathrm{uL}$ of elution buffer instead. DBS were incubated in elution

180 buffer overnight at $4^{\circ} \mathrm{C}$, then spun down at 10,600xg for 10 minutes (min) at $4{ }^{\circ} \mathrm{C}$. The DBS eluate

181 was then transferred to a fresh tube and stored at $4{ }^{\circ} \mathrm{C}$ until analysis.

$182 \quad$ ELISA (N and S)

183 DBS eluates and plasma were evaluated for the presence of IgG against SARS-CoV-2 S and NC

184 using an in-house direct ELISA as previously described(18). Briefly, SARS-CoV-2 antigens were

185 coated in 96-well Nunc Maxisorp ELISA plates (ThermoFisher) overnight at $4^{\circ} \mathrm{C}$. Plates were then

186 blocked in $2.5 \%$ non-fat dry milk in PBS for 2 hours (h) at $37^{\circ} \mathrm{C}$. Plates were washed $3 \mathrm{X}$ with PBS

187 (Gibco), and 100uL of DBS eluate or plasma was diluted 1:100 in 1\% non-fat dry milk and

188 incubated at $37^{\circ} \mathrm{C}$ for $1 \mathrm{~h}$. Plates were then washed 5 times with $0.05 \%$ PBS-Tween-20, and $100 \mathrm{uL}$

189 of goat- $\alpha$-human IgG horseradish peroxidase (HRP) secondary antibody (Fisher) diluted in $1 \%$

190 non-fat dry milk was added. After incubating for $1 \mathrm{~h}$ at $37^{\circ} \mathrm{C}$, plates were washed 5 times in $0.05 \%$

191 PBS-Tween-20 and once in PBS. Wells were developed with TMB (3,3',5,5'-

192 Tetramethylbenzidine, ThermoFisher) for exactly 5 minutes, and the reaction was stopped with

$1932 \mathrm{M} \mathrm{H}_{2} \mathrm{SO}_{4}$. Plates were read on a plate reader at 490nm. Endpoint-titer ELISAs were performed as

194 above, except that the DBS eluate was serially diluted 1:4 or 1:5 eight times in DBS eluate before

195 addition to the plate. Endpoint titers were calculated using the five-parameter logistic equation

196 function in GraphPad Prism 8, using 0.34 as the negative cut-off.

197 Commercial Assays (Ortho $S \&$ Roche N Total IgG Assays)

198 DBS eluates prepared as above (or paired plasma samples for assay validation) were tested with

199 the Ortho VITROS $^{\circledR} \quad$ Anti-SARS-CoV-2 $\quad$ S1 $\quad$ Total Ig assay

200 (https:/www.fda.gov/media/136967/download) or the Roche Elecsys ${ }^{\circledR}$ Anti-SARS-CoV-2 N 
medRxiv preprint doi: https://doi.org/10.1101/2021.11.25.21266786; this version posted November 28, 2021. The copyright holder for this preprint (which was not certified by peer review) is the author/funder, who has granted medRxiv a license to display the preprint in perpetuity.

It is made available under a CC-BY-NC-ND 4.0 International license .

201 Total Ig assay (https://www.fda.gov/media/137605/download) according to the manufacturers'

202 instructions. Briefly, the Ortho VITROS Anti-SARS-CoV-2 total (CoV2T, Ortho-Clinical

203 Diagnostics, Inc.) was used to detect total (IgG, IgM, and IgA) antibodies to SARS-CoV-2 Spike

204 S1 protein. DBS eluates or plasma samples were loaded on Ortho VITROS XT-7600 or 3600

205 instruments (Ortho-Clinical Diagnostics, Inc.) and programmed for the CoV2T test following the

206 manufacturer's instructions. The S1 antigens coated on the assay wells bind anti-S1 antibodies

207 from human serum which, in turn, bind to a secondary HRP-labeled S1 antigen in the conjugate

208 reagent, forming a sandwich. The addition of signal reagent containing luminol generates a

209 chemiluminescence reaction that is measured by the system and quantified as the ratio of the signal

210 relative to the cut-off value $(\mathrm{S} / \mathrm{Co})$ generated during calibration. A $\mathrm{S} / \mathrm{Co} \geq 1$ was considered

211 positive in plasma, while a $\mathrm{S} / \mathrm{Co} \geq 0.7$ in $\mathrm{DBS}$ eluate was considered indeterminate or grey zone

212 (see Results).

213 The Roche Elecsys Anti-SARS-CoV-2 immunoassay (Roche N) was processed on the Cobas e441

214 analyzer (Roche Diagnostics) to detect total antibodies against the SARS-CoV-2 N protein. DBS

215 eluates or plasma samples are initially incubated with biotinylated and ruthenium-labeled SARS-

216 CoV-2 recombinant $\mathrm{N}$ antigens, and any anti- $\mathrm{N}$ antibody present in the solution is sandwiched

217 between the two. Subsequently, streptavidin-coated microparticles are added to the mixture to bind

218 the biotin. The magnetic particles drive the complexes to the electrode, where a chemiluminescent

219 signal is emitted and measured as the ratio between the signal and the cut-off obtained during

220 calibration. $\mathrm{A} S / \mathrm{Co} \geq 1$ in plasma was considered positive, while a $\mathrm{S} / \mathrm{Co} \geq 0.045$ in DBS eluate was

221 considered positive (see Results). 
medRxiv preprint doi: https://doi.org/10.1101/2021.11.25.21266786; this version posted November 28, 2021. The copyright holder for this preprint (which was not certified by peer review) is the author/funder, who has granted medRxiv a license to display the preprint in perpetuity. It is made available under a CC-BY-NC-ND 4.0 International license .

\section{Statistics}

224 Statistical analysis was performed using GraphPad Prism Version 8 (GraphPad Software) and the

225 R statistical programming package.

226

227 All materials and data are available upon request 
medRxiv preprint doi: https://doi.org/10.1101/2021.11.25.21266786; this version posted November 28, 2021. The copyright holder for this preprint (which was not certified by peer review) is the author/funder, who has granted medRxiv a license to display the preprint in perpetuity.

It is made available under a CC-BY-NC-ND 4.0 International license .

\section{$\underline{\text { Results }}$}

\section{DBS are a viable replacement for plasma in multiple serological assay formats}

230 To evaluate whether DBS samples could be a viable replacement for plasma in serosurveillance

231 studies, we first validated the performance of DBS eluates on both an in-house ELISA detecting

232 anti-S IgG and the Ortho CoV2T. To generate DBS for the validation study, we mixed COVID

233 convalescent plasma (CCP) samples from 39 RT-PCR-confirmed SARS-CoV-2-positive patients

234 and 100 pre-2020 negative controls with anticoagulated plasma depleted whole blood to

235 reconstitute whole blood and applied the mixture to the DBS cards ( 15 ul per DBS). Eluates from

236 these reconstituted DBS and their paired plasma samples were then tested by both serological

237 assays.

238 We first tested DBS eluates in our previously validated anti-S IgG ELISA (18). We determined a

239 new cut-off for the anti-S IgG ELISA using DBS eluate as the input (DBS ELISA) as an optical

240 density $\left(\mathrm{OD}_{450)}\right.$ value of 0.34 via receiver-operator curve (ROC) analysis using the convalescent

241 samples following PCR diagnoses and the pre-2020 samples as the reference standards. This cut-

242 off resulted in an overall sensitivity of $97.62 \%$ and specificity of $100 \%$ for the ELISA, which

243 demonstrated 100\% concordance in the SARS-CoV-2-positive samples between the reconstituted

244 DBS eluate and plasma (Figure $2 \mathrm{~A}-\mathrm{B}, \mathrm{S} 1)$. When the recommended threshold (S/Co $\geqq 1)$ on the

245 Ortho CoV2T for detection of anti-S antibodies in plasma/serum was used for DBS eluates, ROC

246 analysis yielded a sensitivity of $79.5 \%$ and specificity of $100 \%$, with an $80 \%$ concordance in the

247 SARS-CoV-2-positive samples between the reconstituted DBS eluates and plasma (Figure 2C-D).

248 Both assays showed a linear relationship between plasma and DBS values (ELISA, $\mathrm{r}^{2}=0.93$; Vitros

$249 \mathrm{r}^{2}=0.78$; Figure $\left.2 \mathrm{~A}, \mathrm{C}\right)$. 
medRxiv preprint doi: https://doi.org/10.1101/2021.11.25.21266786; this version posted November 28, 2021. The copyright holder for this preprint (which was not certified by peer review) is the author/funder, who has granted medRxiv a license to display the preprint in perpetuity.

It is made available under a CC-BY-NC-ND 4.0 International license .

250 We found that the reduced sensitivity of the Ortho CoV2T assay could be explained by the diluted

251 nature of the DBS eluate, as compared to the Ortho CoV2T assay using undiluted plasma. We

252 found that diluting plasma 1:40 gave similar values as the DBS eluates (Figure S2). In contrast,

253 the in-house ELISA was developed using a 1:100 dilution of plasma; thus, DBS eluates performed

254 similarly to plasma in this assay format.

\section{Validation of anti-N serological assays}

256 The introduction of S-based vaccines during the study period necessitated the implementation of

257 N-based serology testing to distinguish between vaccinated and naturally infected individuals in

258 the EBCOVID study. Therefore, we validated an anti-N IgG ELISA for both DBS and serum as

259 well as the Roche $\mathrm{N}$ assay for use with DBS eluates. We determined the positivity cut-off for the

260 anti-N IgG ELISA as an $\mathrm{OD}_{490}$ value of 0.32 via ROC analysis. This cutoff resulted in a sensitivity

261 of $97.1 \%$ and specificity of $91.5 \%$ when testing serum samples (Figure S3A).

262 We performed validation of DBS eluates for the N DBS ELISA using the reconstituted DBS

263 sample set used for the validation of our anti-S antibody assays and determined a positivity cut-

264 off for DBS eluates as an $\mathrm{OD}_{490}$ value of 0.32 via ROC analysis (Figure S3B). This cut-off gave

265 the ELISA an overall sensitivity of $89.7 \%$ and specificity of $90.4 \%$ and $87.1 \%$ concordance in the

266 SARS-CoV-2 positive samples between the reconstituted DBS eluate and plasma (Figure 3A-B).

267 Overall, the DBS eluates and plasma performed similarly in the anti-N IgG ELISA, comparable to

268 our results for the anti-S IgG ELISA.

269 Due to limited sample availability from our validation sample set, we validated the use of DBS

270 eluates on the Roche $\mathrm{N}$ assay using reserved eluates from our Round 2 sampling that preceded

271 vaccine approvals and rollout (Figure 1C). Using our anti-S IgG DBS ELISA as the reference 
medRxiv preprint doi: https://doi.org/10.1101/2021.11.25.21266786; this version posted November 28, 2021. The copyright holder for this preprint (which was not certified by peer review) is the author/funder, who has granted medRxiv a license to display the preprint in perpetuity.

It is made available under a CC-BY-NC-ND 4.0 International license .

272 standard, we determined a new positivity cut-off for the Roche $\mathrm{N}$ assay ( $\mathrm{S} / \mathrm{Co} \geq 0.045)$. With this

273 cut-off, the Roche $\mathrm{N}$ assay displayed a sensitivity of $86.7 \%$ and specificity of $97.9 \%$ using the

274 DBS format (Figure 3C-D).

275 DBS enables serosurveillance in a large longitudinal study during a pandemic

276 Our validation studies demonstrated that DBS are a reliable replacement for plasma, and thus we

277 implemented the use of DBS cards as part of the EBCOVID study. The DBS collected from

278 participants were assessed for quality before processing. Only samples with adequate numbers of

279 saturated DBS were processed in our serological assays; samples that did not meet this criterion

280 were labelled as "Quality Not Sufficient" (QNS), as described above. Overall, we tested 14,782

281 qualified DBS samples from study participants over three rounds of testing.

282 In our first round of testing (July to September 2020), we analyzed 4,670 DBS samples using the

283 Ortho CoV2T Assay and detected anti-S antibodies in 29 individuals as positive ( $\mathrm{S} / \mathrm{Co} \geq 1.0)$, giving

284 an unweighted seroprevalence of $0.6 \%$. Analysis of Round 1 results revealed that $1.08 \%$ of

285 samples had $\mathrm{S} / \mathrm{Co}$ ratios between 0.7 and 1.5 , close to the positivity cutoff of 1.0 set by the

286 manufacturer (Figure S4). Given the linear relationship of DBS eluate to plasma and the dilutional

287 effect attributable to DBS elution seen in our validation of the Ortho CoV2T assay, we reasoned

288 that these samples were likely antibody-positive samples with lower seroreactivity. To better

289 resolve samples with grey-zone reactivity in the Ortho CoV2T in subsequent rounds, we devised

290 an algorithm utilizing the in-house S DBS ELISA to retest samples with Ortho CoV2T S/Co results

291 that fell between 0.7 and 2.0 . 
medRxiv preprint doi: https://doi.org/10.1101/2021.11.25.21266786; this version posted November 28, 2021. The copyright holder for this preprint (which was not certified by peer review) is the author/funder, who has granted medRxiv a license to display the preprint in perpetuity.

It is made available under a CC-BY-NC-ND 4.0 International license .

292 We implemented this algorithm in Round 2 (October to December 2020), testing 5,308 samples

293 by the Ortho Total Ig assay. Of these, 317 samples with $\mathrm{S} / \mathrm{Co}$ values $>0.7$ and $<2.0$ were reflexed

294 to the anti-S IgG ELISA, resulting in $33 \mathrm{~S}$ antibody-positive samples, giving an unweighted

295 seroprevalence of $0.6 \%$ in the cohort in Round 2 (Figure 4).

296 During Round 3 (February to April 2021), vaccines became available to the public, including our

297 study participants. To distinguish between natural infection and vaccine-induced antibody 298 responses, we modified our testing algorithm to include reflex testing for anti-N antibody using

299 the Roche N assay. Round 3 samples were tested first on the Ortho CoV2T assay, and all anti-S300 antibody reactive samples with an $\mathrm{S} / \mathrm{Co}$ ratio $>0.7$ and $<2.0$ were reflexed to the anti-S IgG ELISA, 301 while all anti-S-antibody samples with an $\mathrm{S} / \mathrm{Co}>0.7$ were reflexed to the Roche N DBS assay. We 302 considered a confirmed natural infection as any sample that was positive by anti-S IgG ELISA or 303 had an Ortho CoV2T Assay S/C ratio greater than 2.0 and was positive in the Roche N DBS assay. 304 Using this algorithm, we determined that, of 4,641 samples tested, 1,452 (31.3\%) had anti-S 305 antibodies and 84 (1.8\%) had anti-NC antibodies due to natural infection (Figure 5).

\section{Anti-S antibodies remain stable over time whereas anti-N antibodies appear to wane}

307 Since a key characteristic needed for our study as well as other serosurveillance studies is the 308 ability to accurately track cumulative incidence of infection, we empirically assessed whether the 309 DBS format affected the ability of our serological assays to detect long-term, persistent antibody 310 responses to $\mathrm{S}$ and $\mathrm{N}$. We generated a panel of plasma and reconstituted whole blood DBS from

31110 COVID-19 convalescent plasma donors sampled longitudinally between 0 and 246 days from 312 their first donation and tested this panel using our in-house indirect IgG ELISAs for S and N, the 313 Ortho CoV2T (S) assay, and the Roche N Total Ig assay. The Ortho CoV2T assay showed stable 
medRxiv preprint doi: https://doi.org/10.1101/2021.11.25.21266786; this version posted November 28, 2021. The copyright holder for this preprint (which was not certified by peer review) is the author/funder, who has granted medRxiv a license to display the preprint in perpetuity.

It is made available under a CC-BY-NC-ND 4.0 International license .

314 antibody reactivity over time in plasma and DBS eluates; however, the DBS eluate signal was

315 substantially lower than the signal from neat plasma samples. Our in-house indirect S IgG ELISA

316 also showed antibody stability in both DBS and plasma formats over time, but with similar

317 reactivity observed for plasma and DBS eluates (Figure 6A). In contrast, both the Roche N Total

318 Ig and our in-house indirect N IgG ELISA showed a decrease in antibody reactivity over time in

3196 of 10 donors tested (Figure 6B), although every donor would have still been considered antibody

320 reactive. The signal magnitude of the in-house N ELISA, in both DBS and plasma formats, were

321 comparable to each other as well as to the Roche N plasma results, whereas the Roche N DBS

322 results displayed an overall reduction in signal (Figure 6B). Overall, we found that our serological

323 assays in both plasma and DBS formats were suitable for detection of long-term antibodies against

$324 \mathrm{~S}$ and N.

325 DBS eluates reflect antibody responses after vaccination

326 We next evaluated the ability of our assays to measure the antibody response after vaccination

327 against SARS-CoV-2. We generated a longitudinal panel of DBS following 12 vaccinated

328 individuals sampled before their first dose, after their first dose, and after their second dose and

329 tested this panel using the Ortho CoV2T assay and anti-S ELISA. We found that the while both

330 assays were able to capture the increase of antibodies after the first dose of vaccine, the anti-S

331 DBS ELISA did not show subsequent boosting of the antibody response after the second dose

332 when plotted by optical density (OD) (Figure 7A-C). We reasoned that this was due to saturation

333 of the OD of the anti-S-ELISA; therefore, we performed dilutions of the DBS eluate and generated

334 an endpoint titer for each sample. Determining the endpoint titer effectively increased the dynamic

335 range of the anti-S DBS ELISA and allowed us to capture boosting of the antibody response due

336 to the second dose of vaccine (Figure 7D). We further validated this concept by following the 
medRxiv preprint doi: https://doi.org/10.1101/2021.11.25.21266786; this version posted November 28, 2021. The copyright holder for this preprint (which was not certified by peer review) is the author/funder, who has granted medRxiv a license to display the preprint in perpetuity.

It is made available under a CC-BY-NC-ND 4.0 International license .

337 vaccine antibody response via weekly DBS sampling of a small cohort of 4 individuals over a 338 period of 6 months. Comparisons between the single-dilution OD reading and the endpoint titers

339 revealed that while the single-dilution OD stayed stable across the sampling period, the endpoint

340 titers showed an increase in titers up to four weeks after the second dose and subsequent decline

341 over the next six months (Figure 7E-F). 2 of the individuals also showed an increase in titers after

342 receiving booster doses. These results suggest that our anti-S DBS ELISA is not only able to 343 qualitatively detect persistent antibodies after infection and vaccination but also able to track 344 antibody kinetics by using an endpoint titer method.

\section{Discussion}

346 This study demonstrates that DBS are a suitable replacement for plasma or serum in serological

347 assays and that fingerstick-derived DBS can be effectively implemented for community-based 348 epidemiologic studies. We validated four distinct DBS serological assays with different assay

349 formats and demonstrated that DBS performed similarly to plasma, can be used to detect antibody 350 responses up to 246 days (or more) after infection, and can be used to track antibody kinetics after

351 vaccination. These assays were implemented in a large longitudinal serological survey of 12 cities

352 in the East Bay region of the San Francisco metropolitan area with at-home biospecimen 353 collection, demonstrating the utility of the DBS format for large-scale serosurveillance.

354 Recent work on the topic of SARS-CoV-2 DBS serology has shown that DBS samples and 355 serum/plasma samples perform comparably in most serological assay formats $(9,12,16,17,19)$.

356 One recent study reported that DBS samples could also be adapted for epitope profiling by phage

357 display and for SARS-CoV-2 pseudovirus neutralization (19). These investigators, along with 358 others, validated their serological assays on DBS self-collected by study participants at home and 
medRxiv preprint doi: https://doi.org/10.1101/2021.11.25.21266786; this version posted November 28, 2021. The copyright holder for this preprint (which was not certified by peer review) is the author/funder, who has granted medRxiv a license to display the preprint in perpetuity.

It is made available under a CC-BY-NC-ND 4.0 International license .

359

360

361

362

363

364

365

366

367

368

369

370

371

372

373

374

375

376

377

378

379

380

381

mailed to investigators, providing proof-of-concept that a serological study could be performed using DBS $(17,19,20)$. However, these studies analyzed relatively small number of participants, which limited insights into the scalability of this approach for large epidemiologic studies. Several studies adapted the Roche $\mathrm{N}$ assay, a high-throughput semi-automated commercial assay, for use on DBS eluates to process a larger number of samples. However, since the Roche $\mathrm{N}$ assay only detects antibodies to $\mathrm{N}$, anti-S antibody responses at the population level have yet to be measured in the DBS format. Here, we present extensive validation of both commercial and in-house-derived serological assays against $\mathrm{S}$ and $\mathrm{N}$ and demonstrate the implementation of these methods in a large longitudinal cohort study involving at-home DBS collection by the study participants.

Our S ELISA showed 100\% agreement with plasma and DBS in our validation studies. The Ortho CoV2T assay showed an $80 \%$ concordance between DBS and plasma format at the recommended S/Co cutoff of 1.0, displaying somewhat reduced sensitivity. This loss of sensitivity was attributed to the dilutional effect that occurs during the DBS elution process. We determined that our DBS elution method results in an approximately 1:40 dilution compared to plasma, which is in line with other studies that compared total IgG levels between DBS and plasma (19). This dilutional effect explains why ELISAs perform well when adapted to the DBS format; since most indirect ELISAs are performed with a serum/plasma dilution step, they are less affected by any dilution introduced during the DBS elution step. In contrast, the Ortho and Roche Total Ig sandwich assays are performed using undiluted serum/plasma. When optimizing the Roche $\mathrm{N}$ assay, we were able to adjust the S/Co threshold from 1 to 0.04 based on our performance data and thus improve the sensitivity of the assay in the DBS format. We compensated for the loss of sensitivity in the Ortho S CoV2T assay by reflexing DBS samples with Ortho CoV2T S/Co values that fell within the range of 0.7 to 2 to the in-house anti-S ELISA. 
medRxiv preprint doi: https://doi.org/10.1101/2021.11.25.21266786; this version posted November 28, 2021. The copyright holder for this preprint (which was not certified by peer review) is the author/funder, who has granted medRxiv a license to display the preprint in perpetuity.

It is made available under a CC-BY-NC-ND 4.0 International license .

382 In this study, we were interested in understanding the prevalence of SARS-CoV-2 infection in our

383 study population. Since we used seropositivity as a marker for past infection, it was important to

384 evaluate whether serological assays in the DBS format would be able to detect durable antibody

385 responses months after initial infection. Studies have shown that the durability of SARS-CoV-2

386 antibody responses are variable and depend on assay format, target antigens and severity of disease

387 (20-22). While most individuals had persistent detectable antibodies over 42 weeks post-infection,

388 other individuals demonstrated waning of the antibody response, which correlated with being

389 male, older, and/or having milder disease (21). One study comparing SARS-CoV-2 serological

390 assays using a set of COVID-19 convalescent plasma from a longitudinal cohort 63-129 days

391 following resolution of symptoms showed that some assays, like the Ortho COV2T and the Roche

392 N assays, show stable antibody reactivity over time. while others showed a decline in reactivity

393 (23). We assessed the longitudinal performance of all four serological assays employed in our

394 study using a longitudinal sample set derived from 10 SARS-CoV-2 infected convalescent plasma

395 donors with intervals between resolution of disease symptoms and last donation up to 246 days,

396 using both reconstituted whole blood derived DBS and matched plasma samples. We found that

397 all our assays were consistently able to detect a stable antibody response in previously SARS-

398 CoV-2-infected individuals, although $\mathrm{N}$ antibody responses did show some waning.

399 Recent interest has developed in the waning of SARS-CoV-2 antibody responses after vaccination

400 (24-26). Studies have shown that the antibody response induced by the commonly used mRNA

401 vaccine BNT162b2 (Pfizer-BioNTech) shows a peak in antibody titers several weeks after the

402 administration of the second dose with subsequent decline in total antibody levels and neutralizing

403 antibody titers over a 6-month period $(24,25)$. We showed that an anti-S DBS ELISA could

404 accurately detect these kinetics by performing an endpoint titer on the DBS eluate, adding greater 
medRxiv preprint doi: https://doi.org/10.1101/2021.11.25.21266786; this version posted November 28, 2021. The copyright holder for this preprint (which was not certified by peer review) is the author/funder, who has granted medRxiv a license to display the preprint in perpetuity.

It is made available under a CC-BY-NC-ND 4.0 International license .

405

406

407 level.

408 Finally, we have demonstrated the feasibility of using DBS samples in a large longitudinal study.

409 At-home sample collection and the implementation of DBS enabled the collection of valuable

410 serological data from our study population to investigate changes in seroprevalence over three

411 time-points. Additional examples of how DBS serology data derived from large samples can be

412 successfully used to conduct epidemiologic investigations include our own recent studies. We

413 combined DBS results with comprehensive questionnaire and other publicly available data to

414 estimate population-adjusted SARS-CoV-2 seroprevalence and differences by age, sex,

415 race/ethnicity, zip code, and other demographic strata, and to characterize mitigation behaviors

416 and their effects on SARS-CoV-2 seroprevalence (28). In addition, DBS serology results as

417 described here were also used to assess the relationship between vaccination antibody response

418 and several study participant characteristics including age, sex, vaccine type, vaccine side effects

419 and other health-related factors (O. Solomon and L. Barcellos, unpublished data).

421 In summary, the use of DBS has gained recent interest as an alternative to venous blood sampling

422 due to the COVID-19 pandemic. Many of the strengths of the DBS format (stability at room

423 temperature, less sample volume required, cost-effectiveness) that make them well-suited for

424 serological studies in resource-limited settings also make them an attractive option for SARS-

425 CoV-2 serological surveillance since they enable at-home sampling from study participants.

426 Samples can be returned by mail, safeguarding the health of study participants by avoiding clinic-

427 based phlebotomy. While DBS has been an attractive option for biological sampling in many 
medRxiv preprint doi: https://doi.org/10.1101/2021.11.25.21266786; this version posted November 28, 2021. The copyright holder for this preprint (which was not certified by peer review) is the author/funder, who has granted medRxiv a license to display the preprint in perpetuity.

It is made available under a CC-BY-NC-ND 4.0 International license .

428 fields, lack of validation of DBS on commercial assays/platforms and limited examples of

429 successful implementation have led to reluctance in implementation of DBS sampling for

430 serosurveillance $(7,27)$. Our study presents the validation of two commercial assays, highlighting

431 potential pitfalls due to the dilute nature of the DBS eluate. We also present solutions to mitigate

432 the subsequent reduction in sensitivity when switching from plasma/serum to DBS. We, and

433 others, found that ELISAs were easily modified to accommodate DBS eluates with minimal

434 optimization and with equivalent sensitivity and specificity to plasma/serum. Because ELISAs are

435 also relatively low-cost compared to commercial diagnostic assays, a DBS-based ELISA assay for

436 serosurveillance would be advantageous in resource-limited settings. In addition to providing

437 diagnostic utility, our work and that of others show that DBS eluates can also be used to track

438 antibody kinetics, and can be employed in epitope mapping studies, and even in neutralization

439 assays (19). Our work, combined with evidence from others, makes a strong case for the

440 implementation of DBS, not just for SARS-CoV-2 serological studies but in any other setting

441 where phlebotomy would be impractical.

442

443 Acknowledgments

444 We would like to thank John Pak and Aubree Gordon for the provision of S and N proteins used

445 in the study. We also thank Patrick Hsu and Spotlight Therapeutics for donation of S protein used

446 for assay development. This study was supported by Open Philanthropy Projects, Fast Track grants

447 from Emergent Ventures, the UC Berkeley Innovative Genomics Institute, and the UC Berkeley

448 School of Public Health Center for Population Health. 
medRxiv preprint doi: https://doi.org/10.1101/2021.11.25.21266786; this version posted November 28, 2021. The copyright holder for this preprint (which was not certified by peer review) is the author/funder, who has granted medRxiv a license to display the preprint in perpetuity.

It is made available under a CC-BY-NC-ND 4.0 International license .

\section{References}

450 1. WHO Coronavirus (COVID-19) Dashboard.

451 2. Oran DP, Topol EJ. 2021. The Proportion of SARS-CoV-2 Infections That Are

$452 \quad$ Asymptomatic. Ann Intern Med 174:655-662.

453 3. Sah P, Fitzpatrick MC, Zimmer CF, Abdollahi E, Juden-Kelly L, Moghadas SM, Singer

454 BH, Galvani AP. 2021. Asymptomatic SARS-CoV-2 infection: A systematic review and

455 meta-analysis. Proc Natl Acad Sci U S A 118:e2109229118.

456 4. Mössner BK, Staugaard B, Jensen J, Lillevang ST, Christensen PB, Holm DK. 2016. Dried

457 blood spots, valid screening for viral hepatitis and human immunodeficiency virus in real-

$458 \quad$ life. World J Gastroenterol 22:7604-7612.

459 5. Stefic K, Guinard J, Peytavin G, Saboni L, Sommen C, Sauvage C, Lot F, Laperche S,

460 Velter A, Barin F. 2019. Screening for Human Immunodeficiency Virus Infection by Use of

461 a Fourth-Generation Antigen/Antibody Assay and Dried Blood Spots: In-Depth Analysis of

462 Sensitivity and Performance Assessment in a Cross-Sectional Study. J Clin Microbiol

$463 \quad 58: \mathrm{e} 01645-19$.

464 6. Sarkar S, Singh MP, Ratho RK. 2015. Dried blood spot for Ebola testing in developing

465 countries. Lancet Infect Dis 15:1005.

466 7. Lim MD. 2018. Dried Blood Spots for Global Health Diagnostics and Surveillance:

467 Opportunities and Challenges. Am J Trop Med Hyg 99:256-265. 
medRxiv preprint doi: https://doi.org/10.1101/2021.11.25.21266786; this version posted November 28, 2021. The copyright holder for this preprint (which was not certified by peer review) is the author/funder, who has granted medRxiv a license to display the preprint in perpetuity.

It is made available under a CC-BY-NC-ND 4.0 International license .

468 8. Behets F, Kashamuka M, Pappaioanou M, Green TA, Ryder RW, Batter V, George JR,

469 Hannon WH, Quinn TC. 1992. Stability of human immunodeficiency virus type 1

470 antibodies in whole blood dried on filter paper and stored under various tropical conditions

471 in Kinshasa, Zaire. J Clin Microbiol 30:1179-1182.

472 9. Morley GL, Taylor S, Jossi S, Perez-Toledo M, Faustini SE, Marcial-Juarez E, Shields AM,

473 Goodall M, Allen JD, Watanabe Y, Newby ML, Crispin M, Drayson MT, Cunningham AF,

474 Richter AG, O’Shea MK. 2020. Sensitive Detection of SARS-CoV-2-Specific Antibodies

475 in Dried Blood Spot Samples. Emerg Infect Dis 26:2970-2973.

476 10. McDade TW, McNally EM, Zelikovich AS, D’Aquila R, Mustanski B, Miller A, Vaught

477 LA, Reiser NL, Bogdanovic E, Fallon KS, Demonbreun AR. 2020. High seroprevalence for

478 SARS-CoV-2 among household members of essential workers detected using a dried blood

$479 \quad$ spot assay. PloS One 15:e237833.

480 11. Zava TT, Zava DT. Validation of dried blood spot sample modifications to two

481 commercially available COVID-19 IgG antibody immunoassays. Bioanalysis 10.4155/bio-

$482 \quad 2020-0289$.

483 12. Toh ZQ, Higgins RA, Anderson J, Mazarakis N, Do LAH, Rautenbacher K, Ramos P,

484 Dohle K, Tosif S, Crawford N, Mulholland K, Licciardi PV. 2021. The use of dried blood

485 spots for the serological evaluation of SARS-CoV-2 antibodies. J Public Health

$486 \quad$ 22:fdab011.

487 13. Moat SJ, Zelek WM, Carne E, Ponsford MJ, Bramhall K, Jones S, El-Shanawany T, Wise

488 MP, Thomas A, George C, Fegan C, Steven R, Webb R, Weeks I, Morgan BP, Jolles S. 
medRxiv preprint doi: https://doi.org/10.1101/2021.11.25.21266786; this version posted November 28, 2021. The copyright holder for this preprint (which was not certified by peer review) is the author/funder, who has granted medRxiv a license to display the preprint in perpetuity.

It is made available under a CC-BY-NC-ND 4.0 International license .

2021. Development of a high-throughput SARS-CoV-2 antibody testing pathway using dried blood spot specimens. Ann Clin Biochem 58:123-131.

14. Roxhed N, Bendes A, Dale M, Mattsson C, Hanke L, Dodig-Crnković T, Christian M, Meineke B, Elsässer S, Andréll J, Havervall S, Thålin C, Eklund C, Dillner J, Beck O, Thomas CE, McInerney G, Hong M-G, Murrell B, Fredolini C, Schwenk JM. 2021. Multianalyte serology in home-sampled blood enables an unbiased assessment of the immune response against SARS-CoV-2. Nat Commun 12:3695.

15. Beyerl J, Rubio-Acero R, Castelletti N, Paunovic I, Kroidl I, Khan ZN, Bakuli A, Tautz A, Oft J, Hoelscher M, Wieser A. 2021. A dried blood spot protocol for high throughput analysis of SARS-CoV-2 serology based on the Roche Elecsys anti-N assay. EBioMedicine $70: 103502$.

16. Mulchandani R, Brown B, Brooks T, Semper A, Machin N, Linley E, Borrow R, Wyllie D, Taylor-Philips S, Jones H, Oliver I, Charlett A, Hickman M, Brooks T, Mulchandani R, Wyllie D. 2021. Use of dried blood spot samples for SARS-CoV-2 antibody detection using the Roche Elecsys ${ }^{\circledR}$ high throughput immunoassay. J Clin Virol 136:104739.

17. Karp DG, Danh K, Espinoza NF, Seftel D, Robinson PV, Tsai C. 2020. A serological assay to detect SARS-CoV-2 antibodies in at-home collected finger-prick dried blood spots. Sci Rep 10:20188.

18. Lewnard J, Mora A, Nkwocha O, Kogut K, Rauch S, Morga N, Hernandez S, Wong M, Huen K, Andrejko K, Jewell N, Parra K, Holland N, Harris E, Cuevas M, Eskenazi B. 2021. Prevalence and Clinical Profile of Severe Acute Respiratory Syndrome Coronavirus 2 
medRxiv preprint doi: https://doi.org/10.1101/2021.11.25.21266786; this version posted November 28, 2021. The copyright holder for this preprint (which was not certified by peer review) is the author/funder, who has granted medRxiv a license to display the preprint in perpetuity.

It is made available under a CC-BY-NC-ND 4.0 International license .

Infection among Farmworkers, California, June-November 2020. Emerg Infect Dis J

511 $2021 ; 27(5): 1330-1342$

19. Itell HL, Weight H, Fish CS, Logue JK, Franko N, Wolf CR, McCulloch DJ, Galloway J, Matsen FA, Chu HY, Overbaugh J. SARS-CoV-2 Antibody Binding and Neutralization in Dried Blood Spot Eluates and Paired Plasma. Microbiol Spectr 0:e01298-21.

20. Dorigatti I, Lavezzo E, Manuto L, Ciavarella C, Pacenti M, Boldrin C, Cattai M, Saluzzo F, Franchin E, Del Vecchio C, Caldart F, Castelli G, Nicoletti M, Nieddu E, Salvadoretti E, Labella B, Fava L, Guglielmo S, Fascina M, Grazioli M, Alvisi G, Vanuzzo MC, Zupo T, Calandrin R, Lisi V, Rossi L, Castagliuolo I, Merigliano S, Unwin HJT, Plebani M, Padoan A, Brazzale AR, Toppo S, Ferguson NM, Donnelly CA, Crisanti A. 2021. SARS-CoV-2 antibody dynamics and transmission from community-wide serological testing in the Italian municipality of Vo'. Nat Commun 12:4383.

21. Vanshylla K, Di Cristanziano V, Kleipass F, Dewald F, Schommers P, Gieselmann L, Gruell H, Schlotz M, Ercanoglu MS, Stumpf R, Mayer P, Zehner M, Heger E, Johannis W, Horn C, Suárez I, Jung N, Salomon S, Eberhardt KA, Gathof B, Fätkenheuer G, Pfeifer N, Eggeling R, Augustin M, Lehmann C, Klein F. 2021. Kinetics and correlates of the neutralizing antibody response to SARS-CoV-2 infection in humans. Cell Host Microbe

22. den Hartog G, Vos ERA, van den Hoogen LL, van Boven M, Schepp RM, Smits G, van 29:917-929.e4. Vliet J, Woudstra L, Wijmenga-Monsuur AJ, van Hagen CCE, Sanders EAM, de Melker HE, van der Klis FRM, van Binnendijk RS. 2021. Persistence of antibodies to SARS-CoV- 
medRxiv preprint doi: https://doi.org/10.1101/2021.11.25.21266786; this version posted November 28, 2021. The copyright holder for this preprint (which was not certified by peer review) is the author/funder, who has granted medRxiv a license to display the preprint in perpetuity.

It is made available under a CC-BY-NC-ND 4.0 International license .

2 in relation to symptoms in a nationwide prospective study. Clin Infect Dis Off Publ Infect Dis Soc Am ciab172.

23. Di Germanio C, Simmons G, Kelly K, Martinelli R, Darst O, Azimpouran M, Stone M, Hazegh K, Grebe E, Zhang S, Ma P, Orzechowski M, Gomez JE, Livny J, Hung DT, Vassallo R, Busch MP, Dumont LJ. 2021. SARS-CoV-2 antibody persistence in COVID-19 convalescent plasma donors: Dependency on assay format and applicability to serosurveillance. Transfusion 61:2677-2687.

24. Campo F, Venuti A, Pimpinelli F, Abril E, Blandino G, Conti L, De Virgilio A, De Marco F, Di Noia V, Di Domenico EG, Di Martino S, Ensoli F, Giannarelli D, Mandoj C, Mazzola F, Moretto S, Petruzzi G, Petrone F, Pichi B, Pontone M, Vidiri A, Vujovic B, Piaggio G, Sperandio E, Rosati V, Cognetti F, Morrone A, Ciliberto G, Pellini R. 2021. Antibody Persistence 6 Months Post-Vaccination with BNT162b2 among Health Care Workers. Vaccines 9:1125.

25. Levin EG, Lustig Y, Cohen C, Fluss R, Indenbaum V, Amit S, Doolman R, Asraf K, Mendelson E, Ziv A, Rubin C, Freedman L, Kreiss Y, Regev-Yochay G. 2021. Waning Immune Humoral Response to BNT162b2 Covid-19 Vaccine over 6 Months. N Engl J Med oa2114583

26. Bayart J-L, Douxfils J, Gillot C, David C, Mullier F, Elsen M, Eucher C, Van Eeckhoudt S, Roy T, Gerin V, Wieers G, Laurent C, Closset M, Dogné J-M, Favresse J. 2021. Waning of IgG, Total and Neutralizing Antibodies 6 Months Post-Vaccination with BNT162b2 in Healthcare Workers. Vaccines 9:1092. 
medRxiv preprint doi: https://doi.org/10.1101/2021.11.25.21266786; this version posted November 28, 2021. The copyright holder for this preprint (which was not certified by peer review) is the author/funder, who has granted medRxiv a license to display the preprint in perpetuity. It is made available under a CC-BY-NC-ND 4.0 International license .

552 27. Lange B, Cohn J, Roberts T, Camp J, Chauffour J, Gummadi N, Ishizaki A, Nagarathnam 553 A, Tuaillon E, van de Perre P, Pichler C, Easterbrook P, Denkinger CM. 2017. Diagnostic 554 accuracy of serological diagnosis of hepatitis C and B using dried blood spot samples 555 (DBS): two systematic reviews and meta-analyses. BMC Infect Dis 17:700.

556 28. Adams C, Horton M, Solomon O, Wong MP, Wu SL, Fuller S, Shao X, Fedrigo I, Quach 557 HL, Quach DL, Meas M, Lopez L, Broughton A, Barcellos AL, Shim J, Seymens Y, 558 Hernandez S, Montoya M, Johnson DM, Lewnard J, Beckman KB, Busch MP, Coloma J, 559 Harris E, Barcellos LF. 2021. Impact of individual-level characteristics and virus mitigation 560 behaviors on SARS-CoV-2 infection and seroprevalence in a large Northern California $561 \quad$ cohort. Medrxiv. 
medRxiv preprint doi: https://doi.org/10.1101/2021.11.25.21266786; this version posted November 28, 2021. The copyright holder for this preprint (which was not certified by peer review) is the author/funder, who has granted medRxiv a license to display the preprint in perpetuity.

It is made available under a CC-BY-NC-ND 4.0 International license .

562

563

564

565

566

567

568

569

570

571

572

573

574

575

576

577

578

579

580

\section{Figure Legends}

Figure 1. Schematic of the East Bay COVID (EBCOVID) study. There were 2 phases to the study: (A) the screening phase, where participants were recruited and screened for eligibility for inclusion into our study, and (B-D) the sampling phase, where study participants were invited to provide biospecimens, including DBS, in 3 separate rounds.

Figure 2. Validation of DBS in anti-S serological assays. Paired DBS and plasma samples $(n=39)$ from previously SARS-CoV-2-infected individuals were compared in (A) the anti-S IgG ELISA and (C) the Ortho COV2T assay. DBS samples $(n=100)$ from individuals without previous SARS-CoV-2 infection were analyzed by (B) the anti-S IgG ELISA and (D) the Ortho COV2T assay. Cut-offs for the assays are denoted by dashed lines. Linear regression comparing IgG levels between sample types (A and C) is depicted by a solid line with $95 \%$ confidence intervals (CI).

Figure 3. Validation of DBS in anti-N serological methods. Paired DBS and plasma samples $(n=39)$ from previously SARS-CoV-2-infected individuals were compared in (A) the anti-N IgG ELISA. DBS samples $(\mathrm{n}=100)$ from individuals without previous SARS-CoV-2 infection were analyzed by (B) the anti-N IgG ELISA. Validation of DBS on the Roche $\mathrm{N}$ assay was performed on DBS samples derived from study participants in Round 2 of the EBCOVID study. (C) Samples considered SARS-CoV-2-seropositive $(n=33)$ from the anti-S IgG DBS ELISA were analyzed by the Roche N assay. (D) Samples considered SARS-CoV-2-seronegative ( $n=99)$ by the Ortho COV2T assay were analyzed by the Roche $\mathrm{N}$ assay. Cut-offs for the assays are denoted by dashed lines. Linear regression comparing IgG levels between sample types is depicted by a solid line with $95 \%$ CI. 
medRxiv preprint doi: https://doi.org/10.1101/2021.11.25.21266786; this version posted November 28, 2021. The copyright holder for this preprint (which was not certified by peer review) is the author/funder, who has granted medRxiv a license to display the preprint in perpetuity.

It is made available under a CC-BY-NC-ND 4.0 International license.

586 Figure 4. Testing algorithm and results from EBCOVID Round 2. (A) Schematic of the testing

587 algorithm used for Round 2 of the EBCOVID study. QNS=Quality not sufficient.

588 (B) Round 2 EBCOVID results comparing DBS reflexed according to the testing algorithm on the 589 anti-S IgG ELISA and the Roche $\mathrm{N}$ assays.

591 Figure 5. Testing algorithm and results from EBCOVID Round 3. (A) Schematic of the testing 592 algorithm used for Round 3 of the EBCOVID study. QNS=Quality not sufficient.

593 (B) Round 3 EBCOVID results comparing DBS reflexed according to the testing algorithm on the 594 Ortho CoV2T (Ortho S) and the Roche N assays.

596 Figure 6. Durable SARS-CoV-2 antibody responses to $\mathrm{S}$ and $\mathrm{N}$ can be detected by DBS.

597 Paired plasma (solid lines) and DBS samples (dashed lines) from 10 COVID-19 convalescent 598 plasma donors (L1-L10) sampled longitudinally between 0 and 246 days from their first donation 599 were analyzed by (A) anti-S IgG ELISA and the Ortho CoV2T assay and (B) anti-N ELISA and 600 the Roche $\mathrm{N}$ assay.

601

602 Figure 7. Vaccine-elicited SARS-CoV-2 antibody kinetics can be detected by DBS. 603 (A-B) Plasma and DBS generated from 12 SARS-CoV-2 S-vaccinated individuals sampled before 604 their first dose, after their first dose, and after their second dose were analyzed using the Ortho 605 COV2T assay. DBS from these same individuals were analyzed by the anti-S IgG DBS ELISA as 606 (C) $\mathrm{OD}_{450}$ values or (D) endpoint titers. DBS from 4 other vaccinated individuals sampled weekly 607 after their first, second and third doses were analyzed by the anti-S IgG DBS ELISA as (E) OD 450 
medRxiv preprint doi: https://doi.org/10.1101/2021.11.25.21266786; this version posted November 28, 2021. The copyright holder for this preprint (which was not certified by peer review) is the author/funder, who has granted medRxiv a license to display the preprint in perpetuity. It is made available under a CC-BY-NC-ND 4.0 International license .

608 value or (F) endpoint titer. Solid line in (F) represents positivity cut-off. Dashed lines in (E-F)

609 denote days where additional doses of vaccine were administered. 


\section{Figure 1}
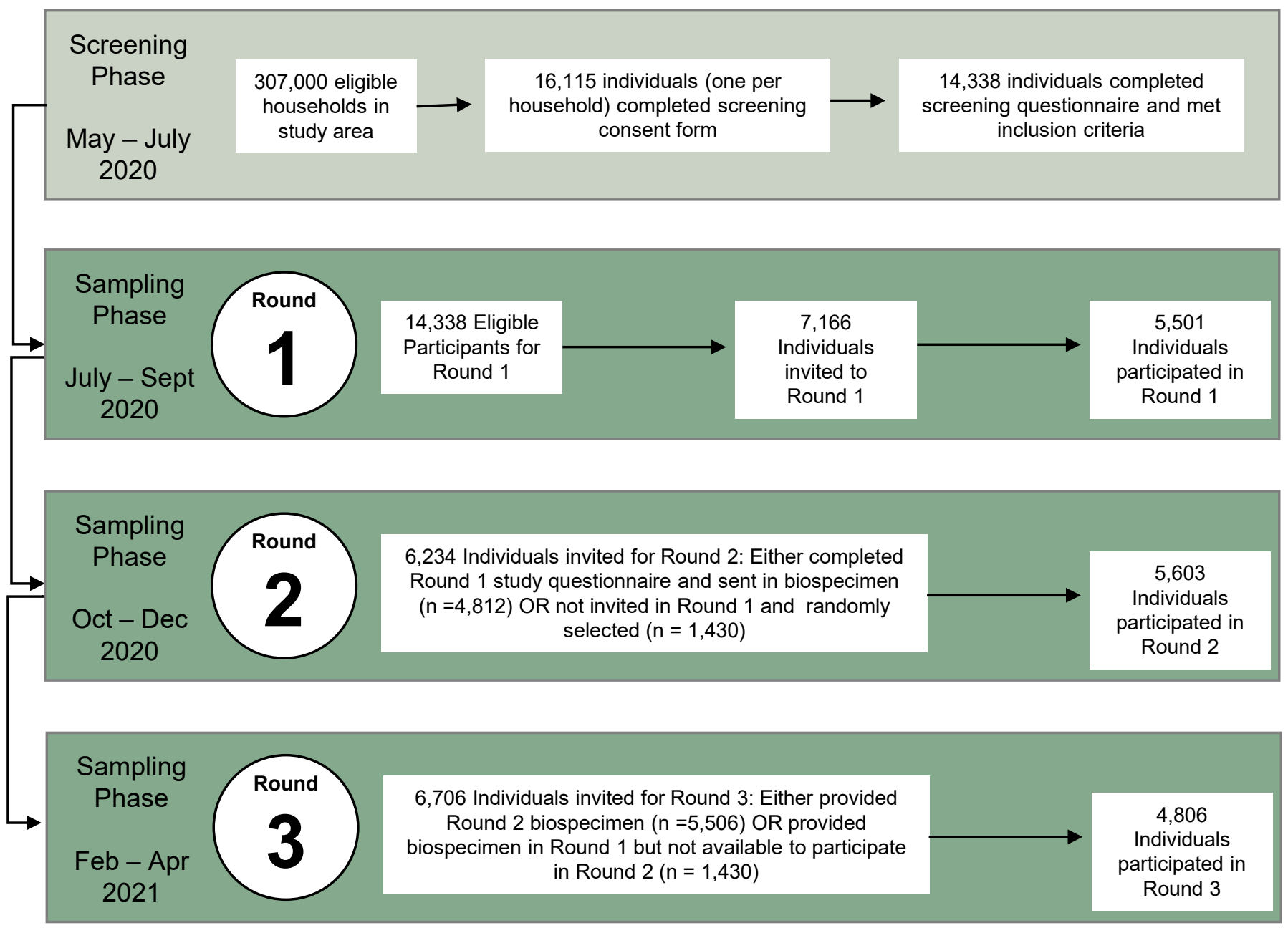
medRxiv preprint doi: https://doi.org/10.1101/2021.11.25.21266786; this version posted November 28, 2021. The copyright holder for this preprint (which was not certified by peer review) is the author/funder, who has granted medRxiv a license to display the preprint in perpetuity. It is made available under a CC-BY-NC-ND 4.0 International license .

1 Figure 1. Schematic of the East Bay COVID (EBCOVID) study. There were 2 phases to the

2 study: (A) the screening phase, where participants were recruited and screened for eligibility for

3 inclusion into our study, and (B-D) the sampling phase, where study participants were invited to

4 provide biospecimens, including DBS, in 3 separate rounds. 
Figure 2

A

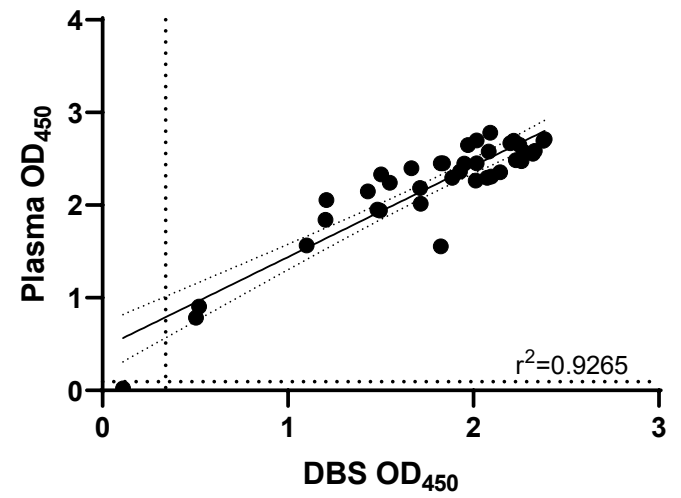

C

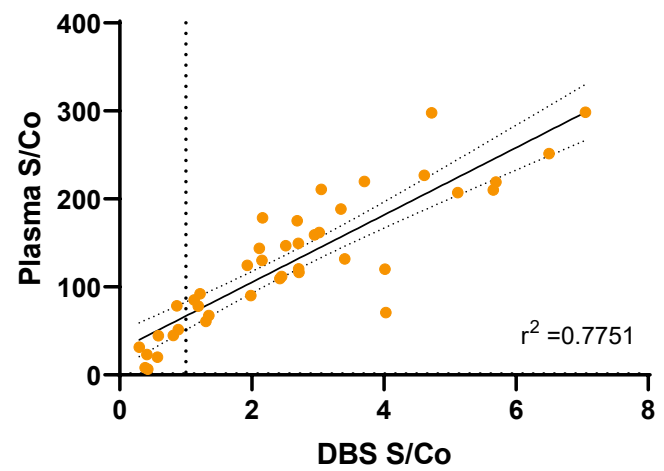

B

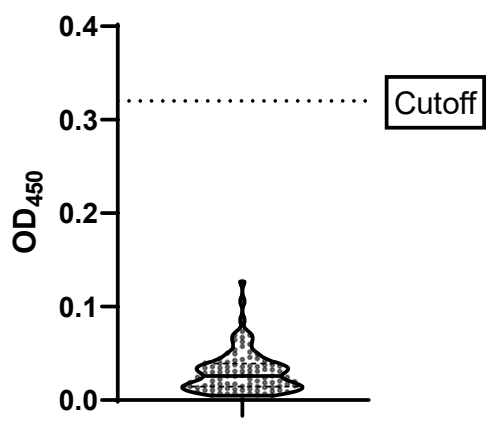

Negative DBS

D

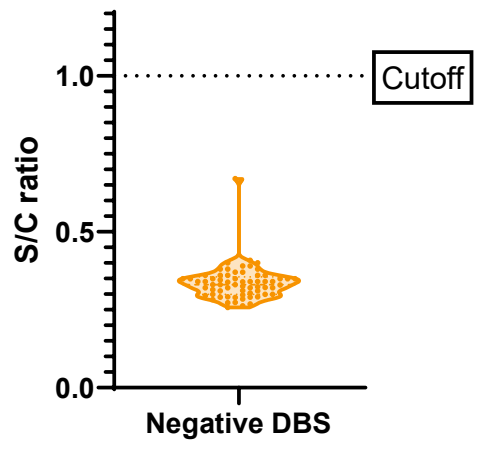


medRxiv preprint doi: https://doi.org/10.1101/2021.11.25.21266786; this version posted November 28, 2021. The copyright holder for this preprint (which was not certified by peer review) is the author/funder, who has granted medRxiv a license to display the preprint in perpetuity. It is made available under a CC-BY-NC-ND 4.0 International license.

8 Figure 2. Validation of DBS in anti-S serological assays. Paired DBS and plasma samples

9 (n=39) from previously SARS-CoV-2-infected individuals were compared in (A) the anti-S IgG

10 ELISA and (C) the Ortho COV2T assay. DBS samples $(\mathrm{n}=100)$ from individuals without

11 previous SARS-CoV-2 infection were analyzed by (B) the anti-S IgG ELISA and (D) the Ortho

12 COV2T assay. Cut-offs for the assays are denoted by dashed lines. Linear regression comparing

13 IgG levels between sample types (A and C) is depicted by a solid line with $95 \%$ confidence

14 intervals (CI). 
Figure 3

A

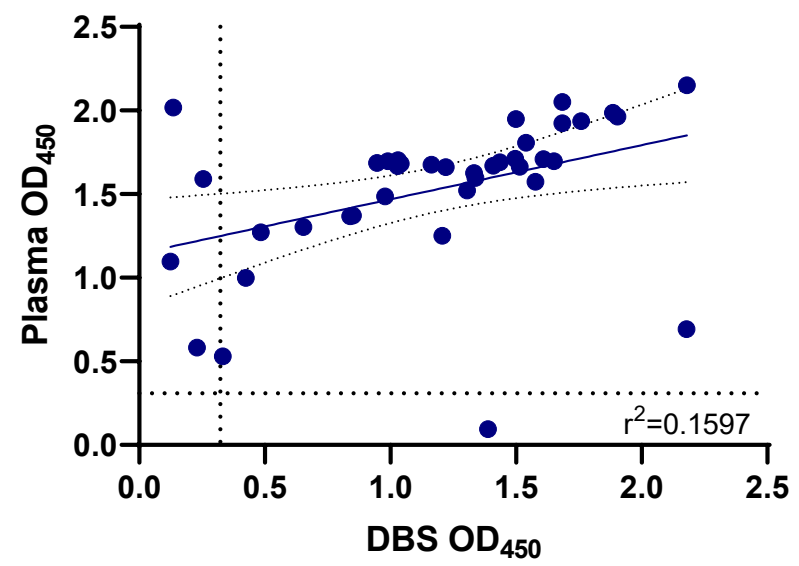

C

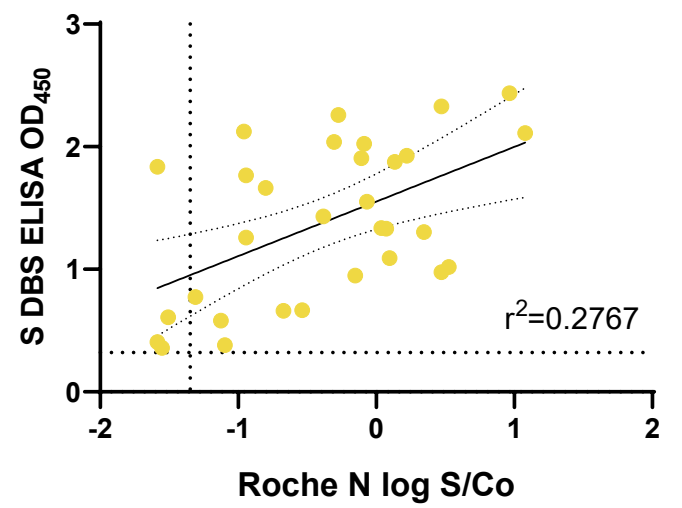

B

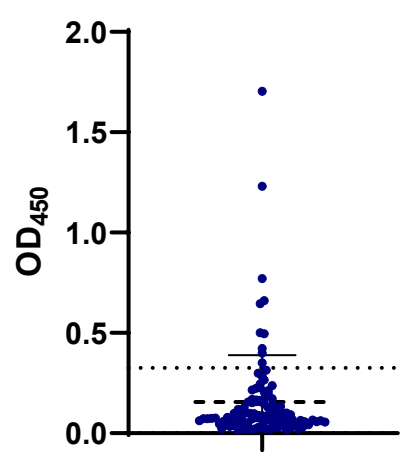

Negative (DBS)

D

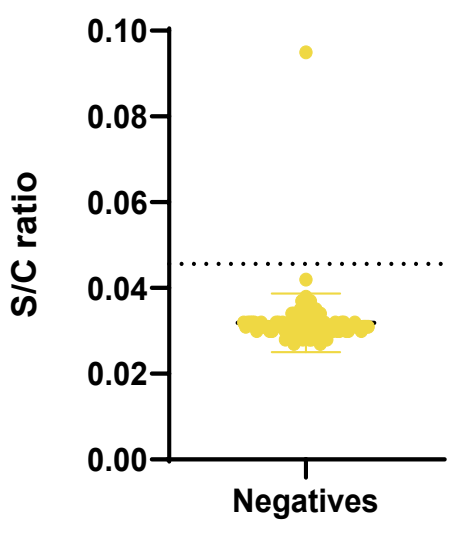


medRxiv preprint doi: https://doi.org/10.1101/2021.11.25.21266786; this version posted November 28, 2021. The copyright holder for this preprint (which was not certified by peer review) is the author/funder, who has granted medRxiv a license to display the preprint in perpetuity. It is made available under a CC-BY-NC-ND 4.0 International license.

17 Figure 3. Validation of DBS in anti-N serological methods. Paired DBS and plasma samples

$18(\mathrm{n}=39)$ from previously SARS-CoV-2-infected individuals were compared in (A) the anti-N IgG

19 ELISA. DBS samples $(\mathrm{n}=100)$ from individuals without previous SARS-CoV-2 infection were

20 analyzed by (B) the anti-N IgG ELISA. Validation of DBS on the Roche N assay was performed

21 on DBS samples derived from study participants in Round 2 of the EBCOVID study. (C)

22 Samples considered SARS-CoV-2-seropositive $(\mathrm{n}=33)$ from the anti-S IgG DBS ELISA were

23 analyzed by the Roche $\mathrm{N}$ assay. (D) Samples considered SARS-CoV-2-seronegative ( $\mathrm{n}=99$ ) by

24 the Ortho COV2T assay were analyzed by the Roche $\mathrm{N}$ assay. Cut-offs for the assays are

25 denoted by dashed lines. Linear regression comparing IgG levels between sample types is

26 depicted by a solid line with $95 \% \mathrm{CI}$.

27 


\section{Figure 4}

A

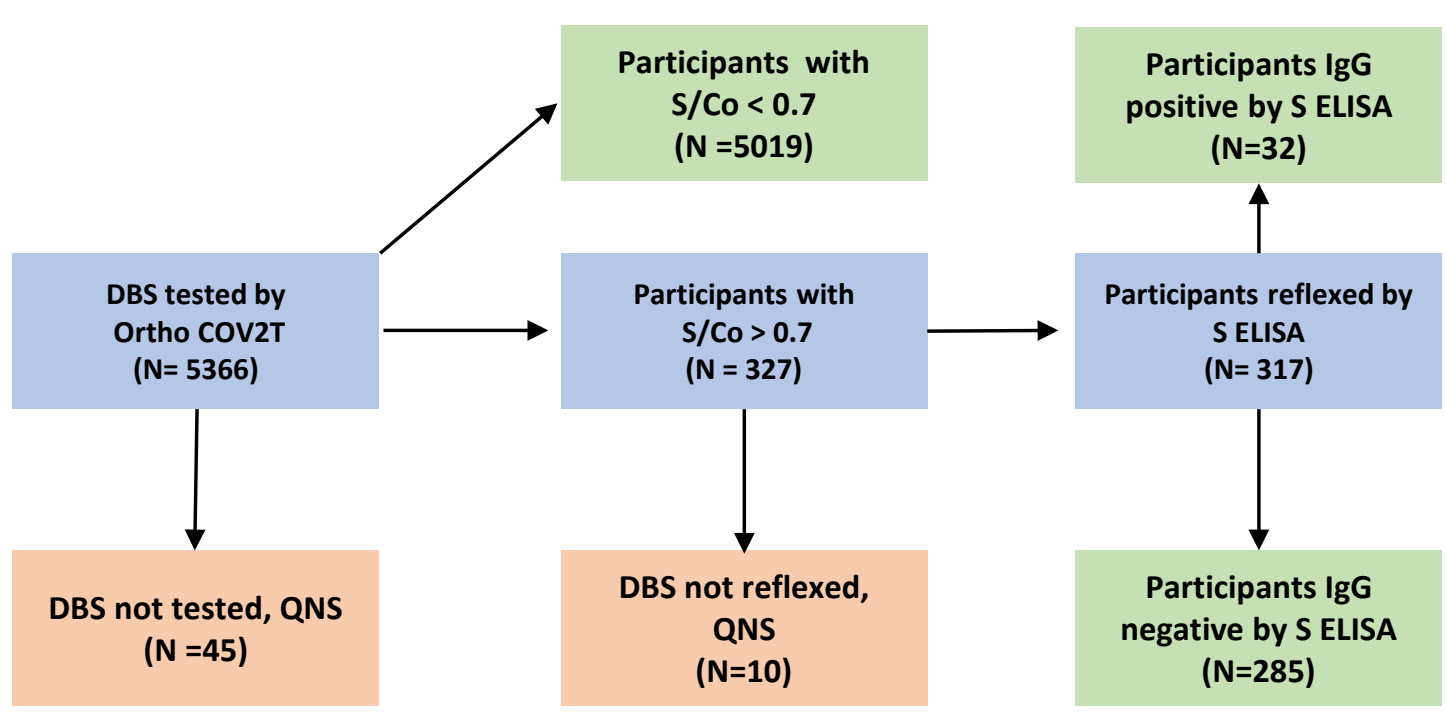

B

Round 2: Roche N vs anti-S IgG ELISA

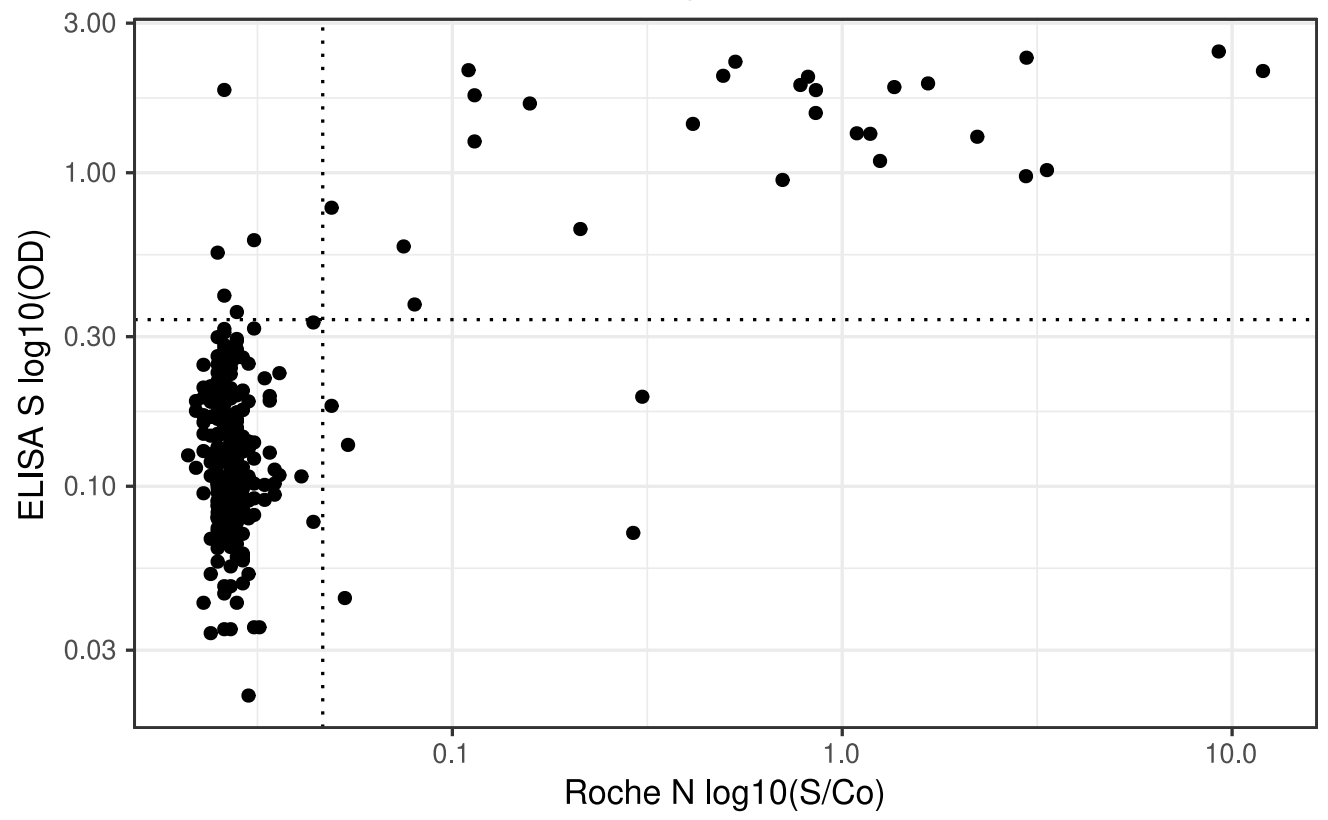


medRxiv preprint doi: https://doi.org/10.1101/2021.11.25.21266786; this version posted November 28, 2021. The copyright holder for this preprint (which was not certified by peer review) is the author/funder, who has granted medRxiv a license to display the preprint in perpetuity. It is made available under a CC-BY-NC-ND 4.0 International license.

28 Figure 4. Testing algorithm and results from EBCOVID Round 2. (A) Schematic of the

29 testing algorithm used for Round 2 of the EBCOVID study. QNS=Quality not sufficient.

30 (B) Round 2 EBCOVID results comparing DBS reflexed according to the testing algorithm on

31 the anti-S IgG ELISA and the Roche $\mathrm{N}$ assays. 
Figure 5 A
$\mathrm{S}+, \mathrm{N}$ - individuals

( $n=1046)$

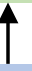

DBS not tested

QNS

$(n=362)$

\section{DBS tested by Ortho \\ COV2T \\ $(n=5004)$}

S/Co $<0.7$ by

Ortho COV2T

$(n=3506)$

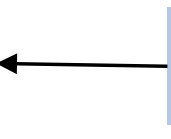

DBS tested by Roche N

( $n=1498)$

$\uparrow$

S/Co $>2.0$ by

Ortho COV2T

(n-1160)

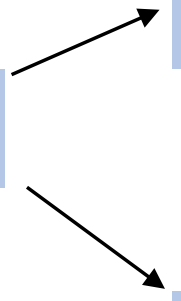

S/Co: $0.7<x<2.0$

by Ortho COV2T

( $n=338)$

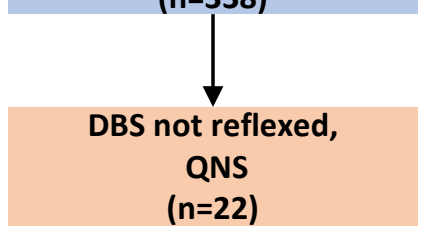

$(n=22)$
$\mathrm{S}+, \mathrm{N}+$ individuals

$(n=84)$
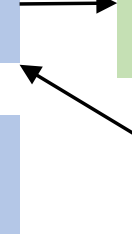

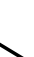
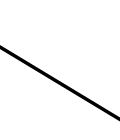

Positive by

$S$ ELISA

$(n=289)$

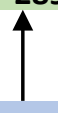

Reflexed by S ELISA

$(n=316)$

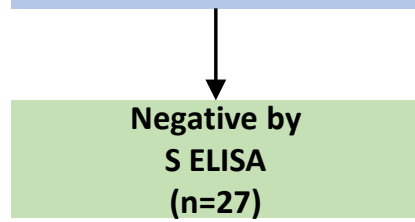

B

Round 3: Roche N vs Ortho CoV2T (S)

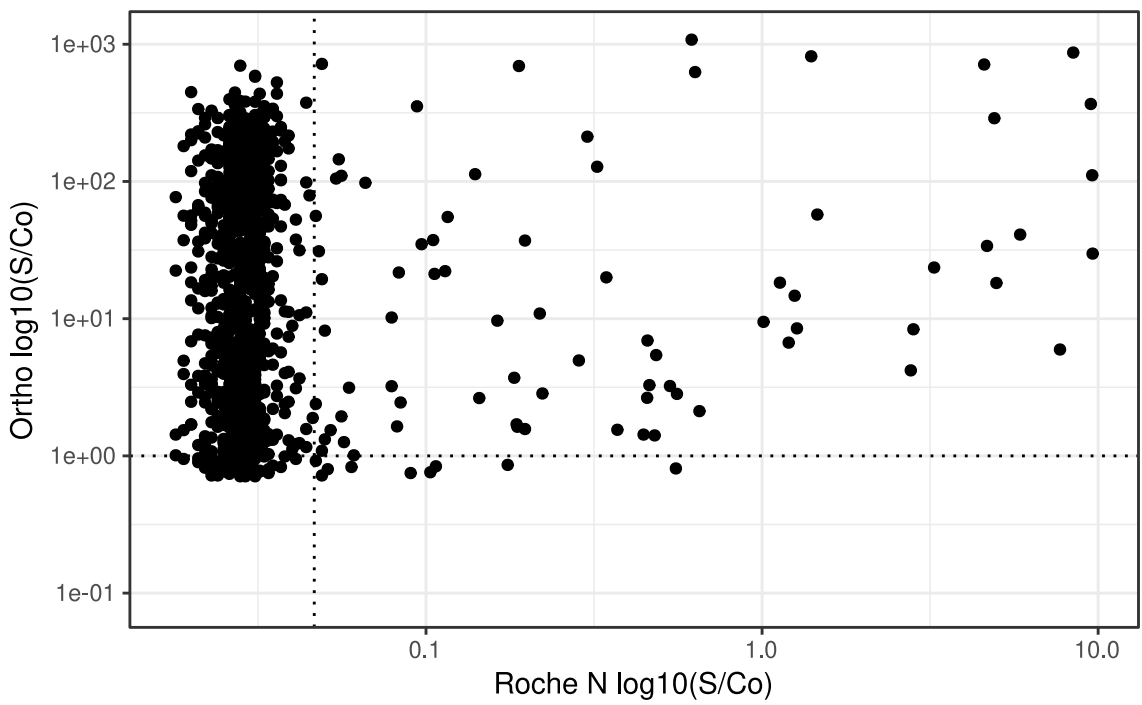


medRxiv preprint doi: https://doi.org/10.1101/2021.11.25.21266786; this version posted November 28, 2021. The copyright holder for this preprint (which was not certified by peer review) is the author/funder, who has granted medRxiv a license to display the preprint in perpetuity. It is made available under a CC-BY-NC-ND 4.0 International license.

33

34 Figure 5. Testing algorithm and results from EBCOVID Round 3. (A) Schematic of the

35 testing algorithm used for Round 3 of the EBCOVID study. QNS=Quality not sufficient.

36 (B) Round 3 EBCOVID results comparing DBS reflexed according to the testing algorithm on

37 the Ortho CoV2T (Ortho S) and the Roche N assays.

38 
A

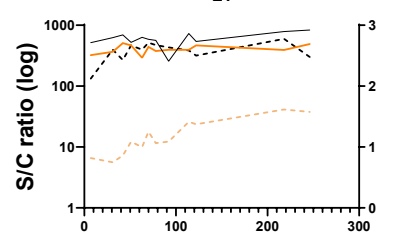

Day since first donation

L5

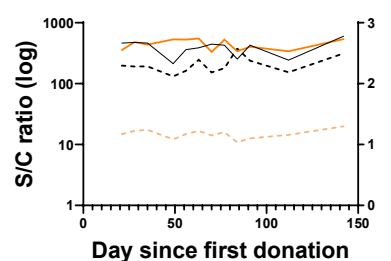

Day since first donation

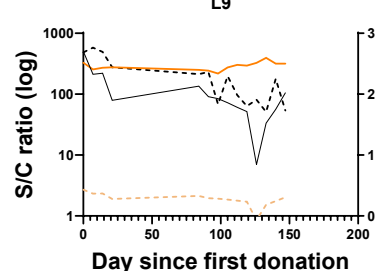

Day since first donation

B

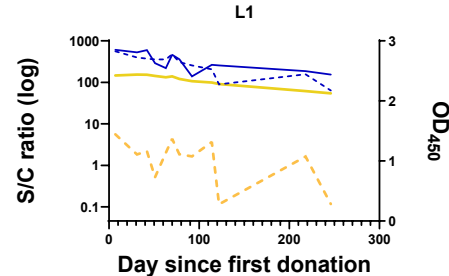

Day since first donation

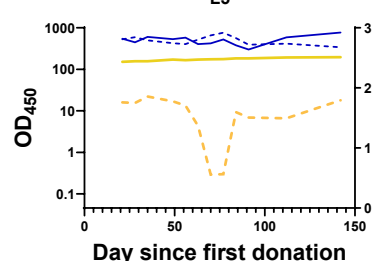

Day since first donation
응

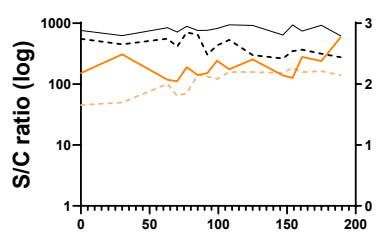

Day since first donation
L3

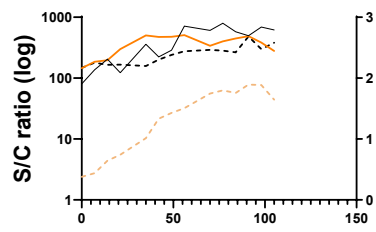

Day since first donation

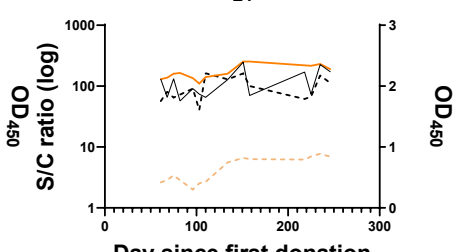

Day since first donation
L6

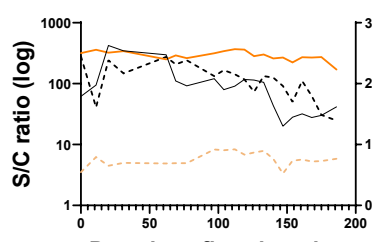

Day since first donation

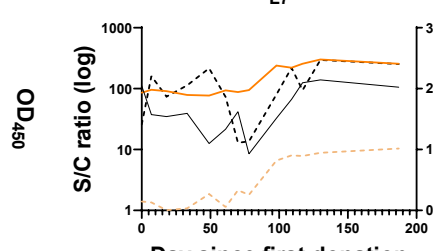

Day since first donation

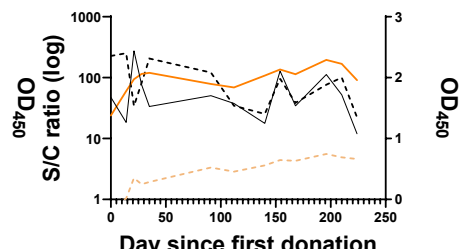

Day since first donation

- Plasma S/Co

- Plasma ELISA OD

-.. DBS S/Co

-.. DBS ELISA OD

\section{Figure 6}

L3

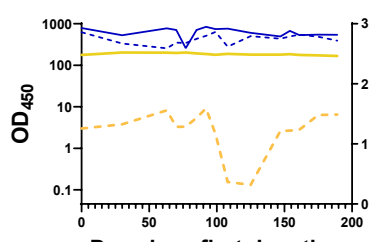

Day since first donation

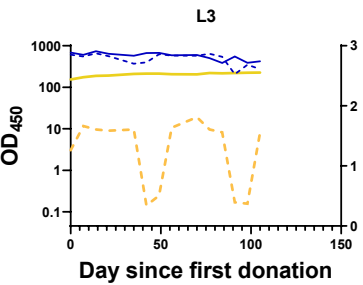

Day since first donation

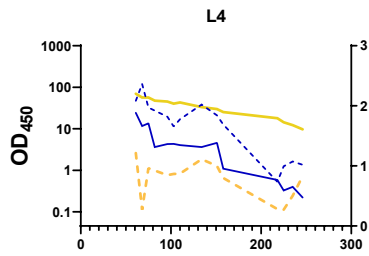

Day since first donation
L6

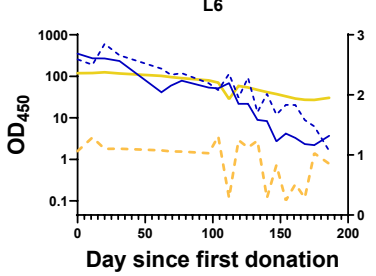

L7

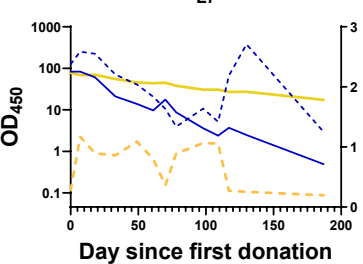

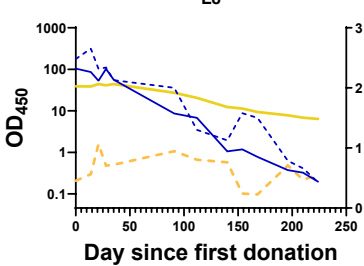

L9

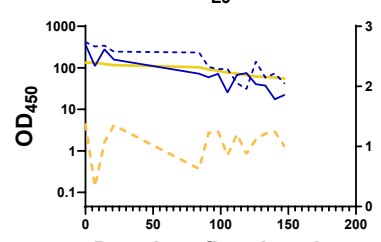

Day since first donation

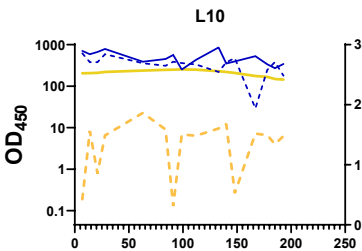

Day since first donation
- Plasma S/Co

- Plasma ELISA OD

- DBS S/Co

-.. DBS ELISA OD 
medRxiv preprint doi: https://doi.org/10.1101/2021.11.25.21266786; this version posted November 28, 2021. The copyright holder for this preprint (which was not certified by peer review) is the author/funder, who has granted medRxiv a license to display the preprint in perpetuity. It is made available under a CC-BY-NC-ND 4.0 International license.

39 Figure 6. Durable SARS-CoV-2 antibody responses to $\mathrm{S}$ and $\mathrm{N}$ can be detected by DBS.

40 Paired plasma (solid lines) and DBS samples (dashed lines) from 10 COVID-19 convalescent

41 plasma donors (L1-L10) sampled longitudinally between 0 and 246 days from their first donation

42 were analyzed by (A) anti-S IgG ELISA and the Ortho CoV2T assay and (B) anti-N ELISA and

43 the Roche $\mathrm{N}$ assay.

44 


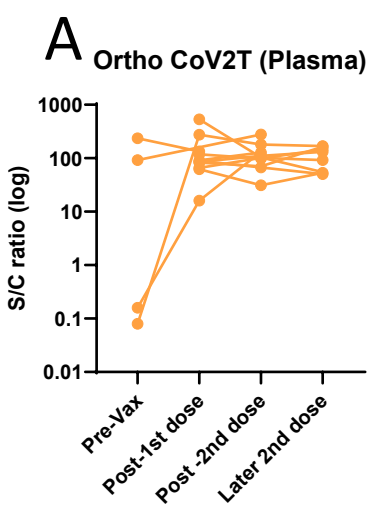

E

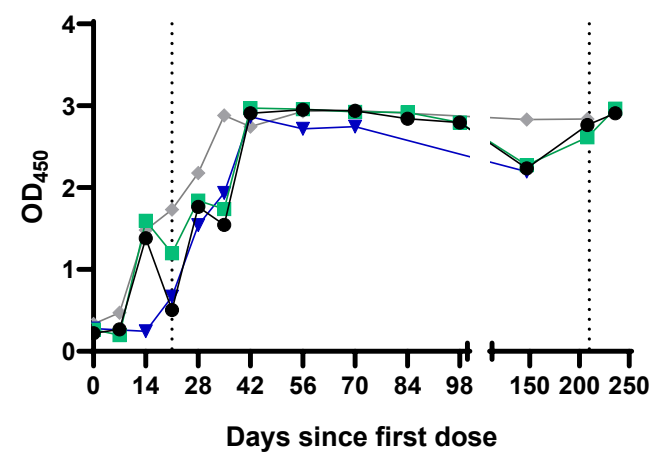

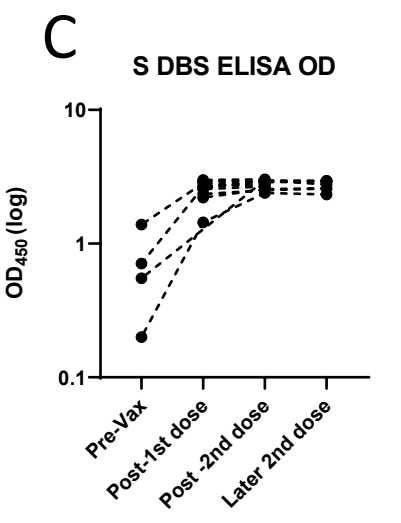
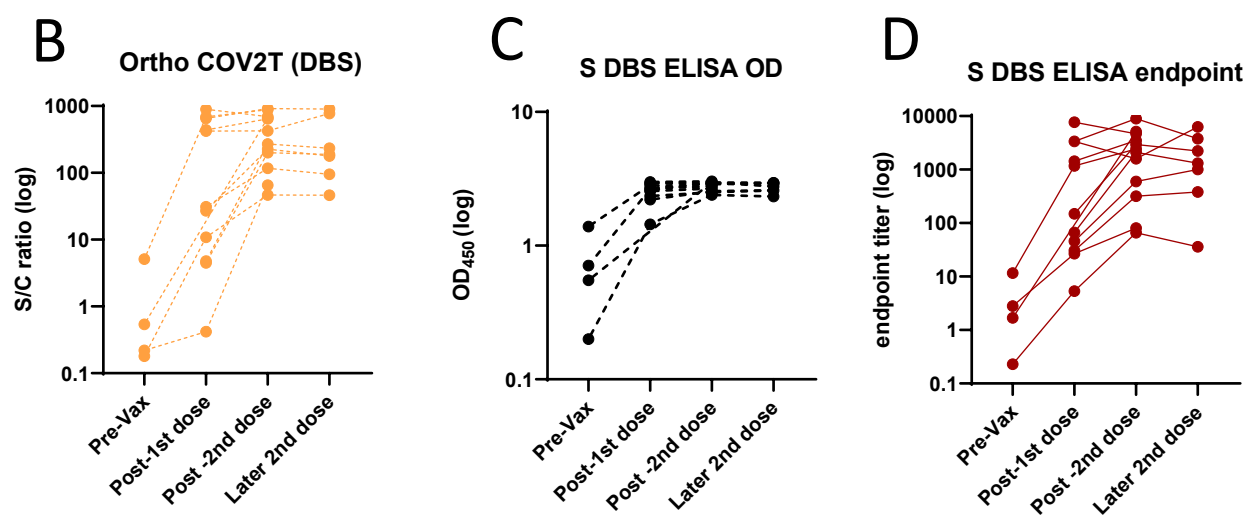

F
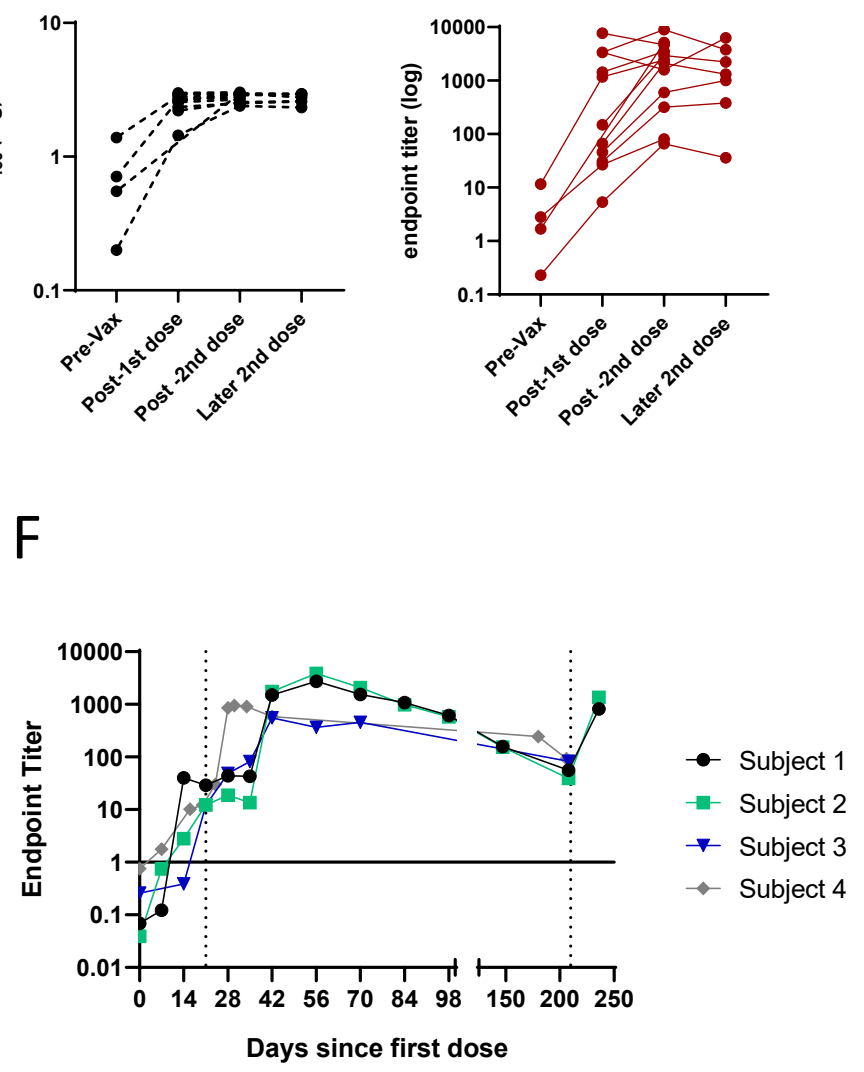
medRxiv preprint doi: https://doi.org/10.1101/2021.11.25.21266786; this version posted November 28, 2021. The copyright holder for this preprint (which was not certified by peer review) is the author/funder, who has granted medRxiv a license to display the preprint in perpetuity. It is made available under a CC-BY-NC-ND 4.0 International license.

45 Figure 7. Vaccine-elicited SARS-CoV-2 antibody kinetics can be detected by DBS.

46 (A-B) Plasma and DBS generated from 12 SARS-CoV-2 S-vaccinated individuals sampled

47 before their first dose, after their first dose, and after their second dose were analyzed using the

48 Ortho COV2T assay. DBS from these same individuals were analyzed by the anti-S IgG DBS

49 ELISA as (C) $\mathrm{OD}_{450}$ values or (D) endpoint titers. DBS from 4 other vaccinated individuals

50 sampled weekly after their first, second and third doses were analyzed by the anti-S IgG DBS

51 ELISA as (E) $\mathrm{OD}_{450}$ value or $(\mathrm{F})$ endpoint titer. Solid line in $(\mathrm{F})$ represents positivity cut-off.

52 Dashed lines in (E-F) denote days where additional doses of vaccine were administered. 